\title{
Zebra Chip Disease Development in Relation to Plant Age and Time of 'Candidatus Liberibacter solanacearum' Infection
}

A. Rashed, University of Idaho, Aberdeen Research and Extension Center, Aberdeen 83210; F. Workneh, L. Paetzold, J. Gray, and C. M. Rush, Texas A\&M AgriLife Research and Extension, Amarillo 79106

\begin{abstract}
Rashed, A., Workneh, F., Paetzold, L., Gray, J., and Rush, C. M. 2014. Zebra chip disease development in relation to plant age and time of 'Candidatus Liberibacter solanacearum' infection. Plant Dis. 98:24-31.

A 2-year field study was conducted to evaluate plant susceptibility to 'Candidatus Liberibacter solanacearum', the putative causal agent of zebra chip disease (ZC). Incubation period of ZC, the rate of symptom progress, and the rate of pathogen population growth were evaluated for individual plants infested on different weeks after emergence. In foliage, incubation period was between 21 and 28 days. The pathogen was detected within leaf tissue in 3 to 4 weeks, regardless of the time of infestation. The rates of foliar symptom progress and pathogen population growth were uniform among all infestations. Although symp-

toms were observed in only $1.3 \%$ of tubers from plants infested 2 weeks before harvest, $74 \%$ of these tubers tested positive for the pathogen. There was a positive correlation between symptom severity and titer in the foliage. Within tubers, however, the relationship was negative but nonsignificant. Pathogen titer reached detectable levels some time between 7 to 14 days following infestation. Although yield reduction was significant only in plants infested during early stages of their growth, chemical management of potato psyllids needs to be continued until at least a week before harvest to minimize ZC impact on the tuber quality.
\end{abstract}

Interconnected biological relationships among pathogen, vector, and host plant, within their environment, form a vector-borne disease complex (8). Quantifying tritrophic ecological interactions, and the environmental factors influencing these interactions, is essential in developing reliable epidemiological models designed to predict disease dynamics, especially for newly emerging diseases.

Zebra chip disease (ZC) of potato (Solanum tuberosum L.) has been a source of major concern to the potato industry for more than a decade (17). ZC is putatively caused by the phloem-limited bacterium 'Candidatus Liberibacter solanacearum' (13,23), transmitted by the potato psyllid Bactericera cockerelli Sulc (Hemiptera: Triozidae) $(6,17)$. The pathogen is closely related to the causal agent of citrus greening, 'Candidatus Liberibacter spp.' gram-negative $\alpha$-proteobacteria $(9,14)$.

$\mathrm{ZC}$ results in yield loss and negatively impacts quality due to undesirable browning in potato tubers. Browning of the vascular and medullary ray tissue within infected tubers is a diagnostic characteristic of $\mathrm{ZC}$ and becomes more pronounced on frying. This trait has reduced the marketability of potato grown for chips and fries $(17,23)$. Excessive browning of fried ZC-affected potato has been attributed to elevated amino acids and reducing sugars $(20,26)$. When exposed to high temperatures, these two biochemical components react to form a brown-colored product known as acrylamide (24). Foliar symptoms of ZC include curling of the leaves, shortened internodes, leaf chlorosis and necrosis, and, eventually, vine collapse and death. These symptoms are similar to some other potato diseases; namely, potato purple top and psyllid yellows $(15,23)$.

B. cockerelli is a highly efficient vector of ' $\mathrm{Ca}$. L. solanacearum' in the potato host $(3,19)$. However, anecdotal observations have indicated that, even with bacteriliferous psyllids present early in the season, ZC symptoms typically do not appear until after flowering, approximately 1 month after plant emergence. This

Corresponding author: A. Rashed, E-mail: arashed@uidaho.edu

Accepted for publication 15 July 2013.

http://dx.doi.org/10.1094/PDIS-04-13-0366-RE

(C) 2014 The American Phytopathological Society observation suggests that potato plants may be more susceptible at certain developmental stages, or that the vector may preferentially infest the host at a particular stage of plant growth. If either of these were confirmed, it could affect producer decisions on psyllid management. Currently, there are no potato cultivars with economically acceptable levels of resistance to $\mathrm{ZC}$; frequent insecticide applications have been somewhat successful in limiting vector populations and disease incidence (5). However, emergence of insecticide-resistant populations of potato psyllid in southern Texas (D. C. Henne, personal communication) highlights the importance of developing management strategies that incorporate fewer yet more targeted chemical applications. An understanding of disease development during the growing season and host susceptibility to infection are essential for development of an economic threshold and a sustainable management program.

This study complemented the existing knowledge of etiology and epidemiology of ZC by (i) quantifying pathogen population growth, the disease incubation period, and symptom progress following disease appearance in both foliar and tuber tissues and (ii) comparing potato plant susceptibility to infections occurring at different developmental stages in the field. The tuber yield of plants infested at different developmental stages also was determined and compared at harvest.

\section{Materials and Methods}

Field studies were conducted at the Texas A\&M AgriLife Research Experiment Station in Bushland in two successive years. Seed potato tubers of 'FL 1867' were planted in April 2011 and 2012. Tent-shaped 100-by-100-by-100-cm mesh cages were established prior to emergence, using Sunguard II fiber glass rods (Geotek Inc.) and fine "netting 750" mesh (U.S. Global Resources). The potato plants emerged in May, approximately 1 month after planting. Following emergence, plants in each cage were thinned to four, so that one plant was located at each corner of the cage. An onsite weather station collected meteorological data.

Potato psyllids, used as vectors, were of a central haplotype (25) and carried a mixture of LsoA and LsoB pathogen biotypes (27). Colonies were initiated from psyllids provided by Dr. C. Nansen's laboratory at the Texas A\&M Agrilife Research Center, Lubbock, and maintained in two 60-by-60-by-60-cm mesh-and-clear plastic bugdorm 2 cages (BioQuip). The psyllids were originally collected by Dr. J. Munyaneza from ZC-affected fields in Texas. In each of 
the bugdorm cages, insects were reared on four to five potato plants (FL 1867). Dead plants were replaced every 5 to 6 weeks so that the insects had continuous access to ZC-affected plants. The average daily temperature in the greenhouse was $24.0^{\circ} \mathrm{C}( \pm 0.1$ standard error).

To confirm the infectivity of the greenhouse colonies, random samples were tested by quantitative polymerase chain reaction (qPCR) (described below) prior to each time plants were infested ("treatment"). For the first two treatments, 10 randomly selected psyllids from each colony were tested individually. For each of the remaining infestation treatments, five composite samples of 2 to 3 psyllids (2011) or two to three composite samples of 10 psyllids (2012) were used to confirm the colony status. Psyllids always tested positive for the pathogen. In a previous study (19), the frequency of infected psyllids in greenhouse colonies was estimated to be $97 \%$.
To inoculate plants with the pathogen, 30 potato psyllids from infected colonies were released at the base of a single plant (plant 1) located in the front-left corner of each experimental cage. Plants 2,3 , and 4 were located in the remaining three corners of the cage, approximately $50 \mathrm{~cm}$ apart. There were a total of nine infestation treatments between May and July 2011 and 2012. Field cages were infested every 7 days, starting 1 week after plant emergence and continuing until 1 week before harvest, in the last week of July. Therefore, the first infestation, 1 week after plant emergence, allowed for 9 weeks of disease development. The last infestation, performed 1 week before harvest, only allowed for 1 week of disease development. Based on this approach, early infestations coincided with earlier developmental stages of potato plants.

In each year, there were 4 cages for each of the nine infestation treatments, arranged in a randomized complete block design (a total of 36 cages of infested plus 4 uninfected controls). The plants
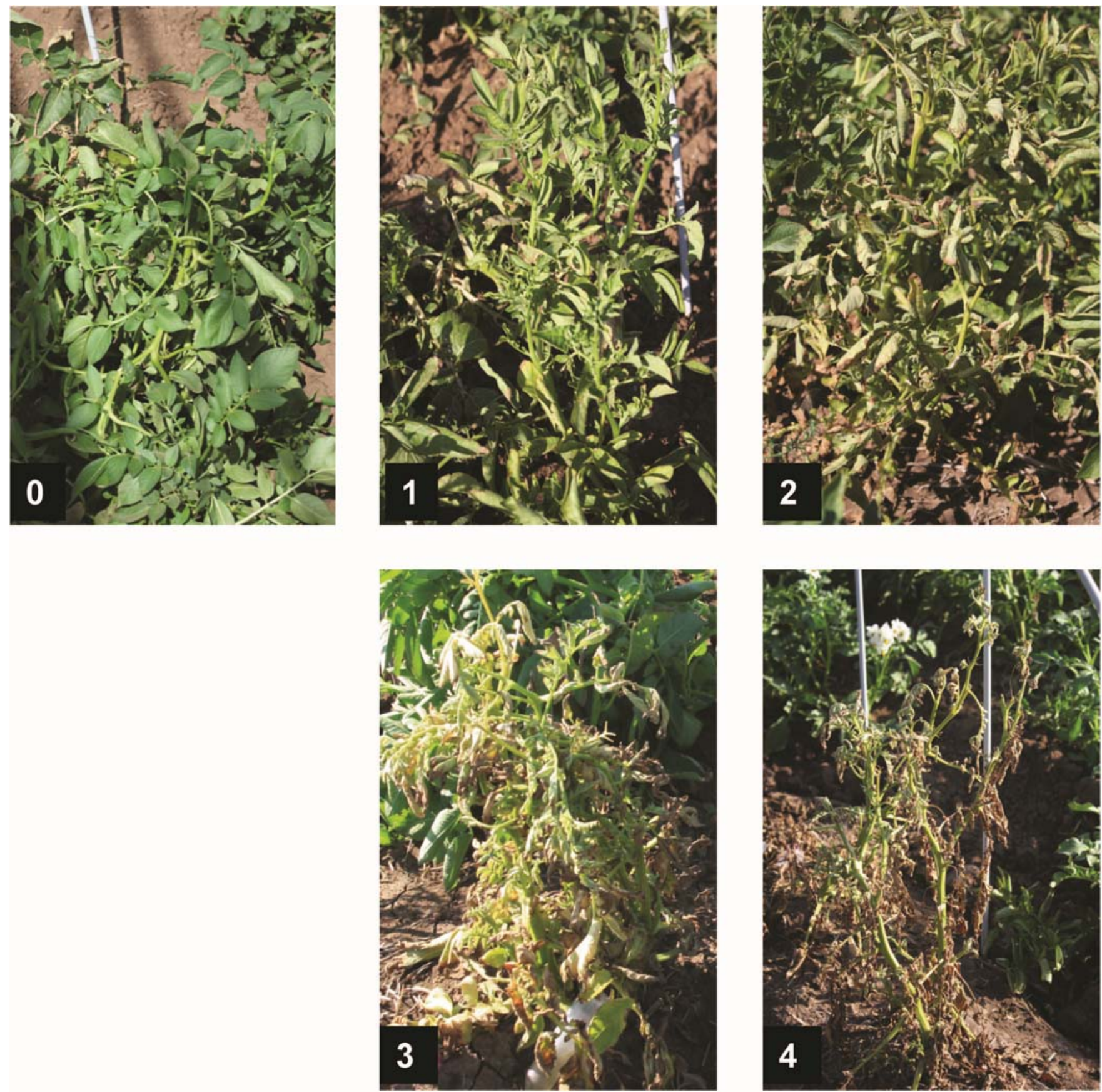

Fig. 1. Zebra chip disease severity scale used for assessing foliar symptoms in this study ('FL 1867'); $0=$ no disease; $1=$ upward curling and early chlorosis of leaves; $2=$ aerial tubers, leaf curling, chlorosis, and necrosis on the leaf edges; $3=$ wilt, sever necrosis of leaves and branches with necrosis; and $4=$ vine collapse, advanced necrosis, scorching of all leaves. 
in each infested cage were exposed to infective psyllids for a 1week period. After the 1-week exposure period, plants were sprayed with a tank mix of Movento (Bayer CropScience), AgriMek, and Fulfill (Syngenta Crop Protection, LLC) to remove the psyllids. To ensure that all psyllids were killed, plants were sprayed again the following week. The plants were scored for foliar symptom severity twice a week. A scale of 0 to 4 was used, where $0=$ no symptoms; 1 = curling and early chlorosis of newly emerged terminal leaves; 2 = some aerial tubers, majority of leaves with curling, chlorosis, and necrosis on the edges; 3 = plant wilt, a majority of leaves and branches with necrosis; and $4=$ vine collapse, advanced necrosis, scorching of all leaves (Fig. 1). If the severity of symptoms was between two numbers, we used the designation 0.5 .

To quantify changes in ' $\mathrm{Ca}$. L. solanacearum' titer, leaf samples were collected and analyzed molecularly. The youngest fully expanded leaf on a single stem of each plant was removed in each of the weekly samplings conducted in 2011 and 2012. In 2011, weekly samplings were started 1 week after each of the infestation treatments and continued until harvest. In all of the collected leaf samples, the pathogen remained undetectable for the first 2 weeks after infestation. Therefore, in 2012, leaf samples were collected starting week three post infestation (skipping the first 2 weeks), then continued weekly for four consecutive weeks. At harvest, all plants were sampled by removing the terminal portion of one stem per plant.

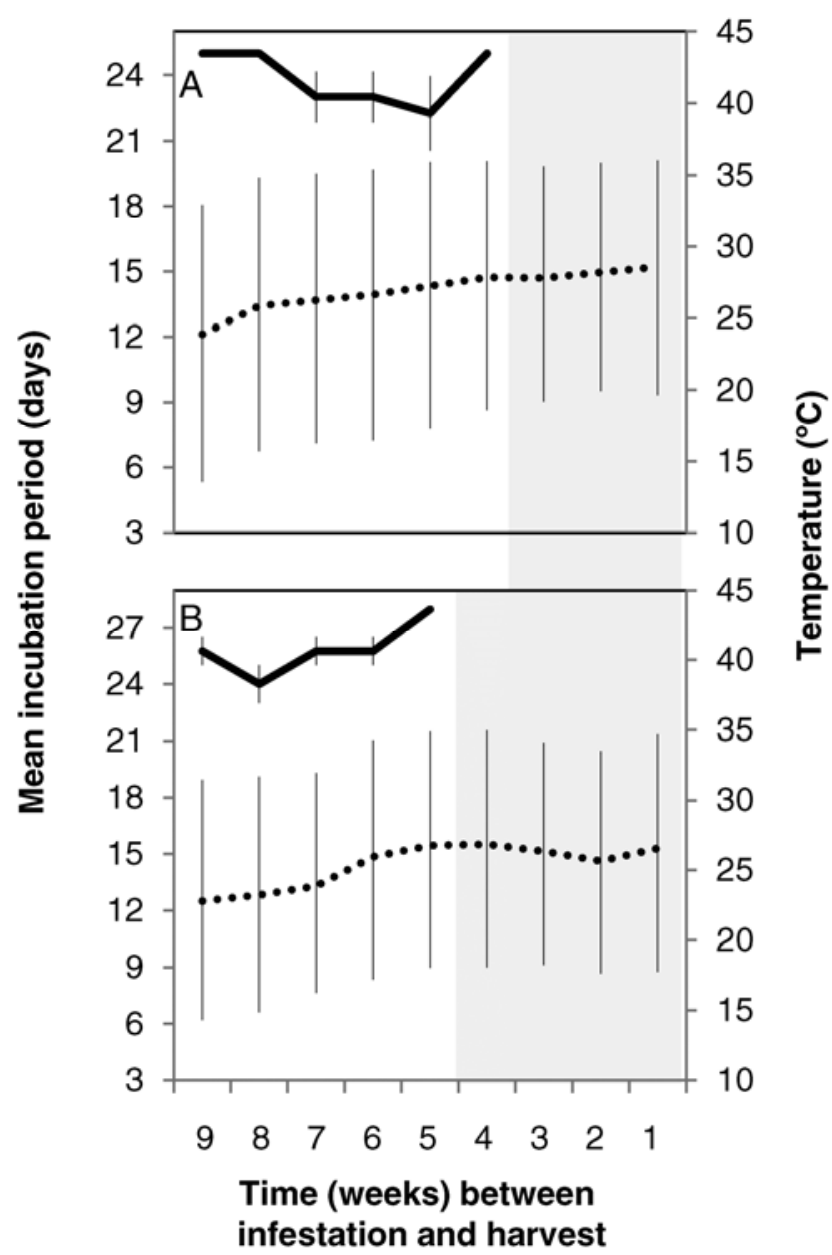

Fig. 2. Mean disease incubation period (solid line) and mean daily temperatures (dotted line) during a 3-week period following infestation in A, 2011 and B, 2012 across different infestations (different durations of infection). Shaded area highlights plant treatments that did not express foliar zebra chip disease symptoms. Error bars on temperature lines represent means of maximum and minimum daily temperatures during a 3-week period after each infestation event. Incubation period error bars represent standard error $( \pm 1)$.
Tubers from the individual plants in each cage were collected at harvest and transferred to the laboratory for processing. Tubers from psyllid-free cages were used as negative controls and never tested positive for the pathogen. The total number of harvested tubers per plant was recorded and a $0.5-\mathrm{cm}$ slice was removed from the basal end (stolon attachment point) of each tuber. The tuber slices were rated for symptom severity, following a 0-to-3 scale described by Rashed et al. (20). This scale was established based on the surface area affected and the intensity of the discolored tissue (20). A 100-mg tissue sample was removed from the slice and the pathogen titer was quantified (described below). All leaf and tuber tissue samples not processed immediately were stored at $-80^{\circ} \mathrm{C}$ until processing.

DNA extraction and pathogen quantification. A slightly modified DNeasy Plant Mini Kit (Qiagen) protocol was used for plant extractions. Processed samples were removed from $-80^{\circ} \mathrm{C}$ storage and placed in liquid nitrogen. Then, samples were ground twice in a homogenizer (VWR), for $3 \mathrm{~min}$, with a 5-mm stainless steel bead. The final DNA product was eluted in $100 \mu \mathrm{l}$ of the elution buffer.

A comparative cycle threshold $(\mathrm{Ct})$ method $(\Delta \Delta \mathrm{Ct})$ was used to quantify the pathogen in both tuber and foliar tissue, using an Applied Biosystems 7500 Real-Time PCR System. The reaction mix contained TaqMan Universal Master Mix (Applied Biosystems), $0.3 \mu \mathrm{M}$ forward primer $\mathrm{LsoF}$ (11), $0.3 \mu \mathrm{M}$ reverse primer HLBr (12), and $0.25 \mu \mathrm{M}$ HLBp TaqMan probe (12). Eukaryotic $18 \mathrm{~S}$ ribosomal RNA (VIC/MGB probe, primer limited; Applied Biosystems) was used as the endogenous control. The quantity of ' $\mathrm{Ca}$. L. solanacearum' was normalized to the endogenous reference and quantified in relation to a calibrator (20) containing 50,000 genome copies for tuber tissue and 6,250 genome copies for petiole tissue. Multiple plates were analyzed at the same time, using the plate study function of ABI default analysis software.

Statistical analyses. For all analyses, SPSS software (version 21.0; IBM) was used. As mentioned earlier, psyllids were released on a single plant (plant 1 ) in every cage. A two-way analysis of variance (ANOVA) was performed to compare the disease incubation period among the four plants within a cage. For this analysis, year, infestation date, cage replicate, and plant number were treated as factors. This analysis revealed a nonrandom pattern in symptom appearance among the four plants, indicating a heterogeneous spatial or temporal distribution of the psyllids. Therefore, for consistency, comparisons of ZC incubation period, the rate of progress in foliar symptoms (after initial visual detection), the rate of pathogen population growth, and final tuber symptom scores among infestation treatments were based on data from plant 1 , on which the infective psyllids were initially released.

Mean tuber symptom scores, ZC incubation period, the daily rates of symptom progress, and pathogen population growth in the foliage across infestation treatments were compared by ANOVA. Year, plant replicate, infestation date ("infection duration"), and year-infestation interaction term were factors included in all of the initial statistical models. A stepwise approach was taken to remove year, plant replicate, and their interaction term when their effects were nonsignificant (only if $P>0.08$ ).

To analyze tuber symptoms, the scores of all tubers harvested from each plant were averaged. Log-transformed average tuber scores provided the closest fit to normality. Likewise, for each plant, relative ' $C a$. L. solanacearum' titer was averaged across all tubers. Log-transformed quantities were normally distributed within infestation treatments (Kolmogorov-Smirnov, $P>0.10$ ), with the exception of the first infestation (Kolmogorov-Smirnov, $P$ $=0.040)$. A value of one was added to averaged symptom scores and averaged relative ' $\mathrm{Ca}$. L. solanacearum' quantities to produce positive values.

Daily rate of foliar symptom progress was estimated by subtracting the $\mathrm{ZC}$ score on the day it was first detected from the $\mathrm{ZC}$ symptom score of about 3 (2.5 to 3.5$)$. The resulting value was then divided by the number of days elapsed between first detection and severity score 3 . Similarly, the daily rate of pathogen popula- 
tion growth was calculated by subtracting the initial amount detected in the leaves from the titer at harvest, then dividing the resulting value by the number of days. Plants inoculated during the last four infestation dates were not included in these analyses because they had no symptom scores above 1 or had sufficient numbers of samples positive for ' $\mathrm{Ca}$. L. solanacearum' for population growth rate calculations. The log-transformed daily symptom progress and titer increase rates were normally distributed within all infestations (Kolmogorov-Smirnov, $P>0.06$ ).

ANOVA was also used to compare potato yield among different infestation dates. Year, treatment, and plant replicate were included as factors in the initial model. Similar to previous analyses, largely nonsignificant effects were removed in a stepwise approach.

Pearson correlation was used to evaluate the relationship between the bacterial titer within tubers and average symptom severity. Spearman $\rho$ correlation was applied to evaluate the relationship between symptom score and titer levels within petiole tissue.

\section{Results}

ZC development in potato foliage. Plants infested less than 3 weeks before harvest (the last three infestations) did not develop foliar symptoms, nor did the noninfected controls. Disease incubation period (time between infestation and symptom appearance) in the foliage was not affected by infestation treatment (ANOVA: $\mathrm{F}_{5,31}=0.1 .31, P=0.286$ ), even though considerable variation in ambient temperatures occurred during the course of plant development (Fig. 2A and B). On average, the first ZC symptoms appeared $24.1( \pm 0.3)$ days post infestation in 2011 and after $25.7( \pm 0.4)$ days in 2012. Year $\left(F_{1,31}=13.13, P=0.001\right)$ and year-infestation date treatment $\left(F_{4,31}=3.10, P=0.030\right)$ had significant effects on dis-

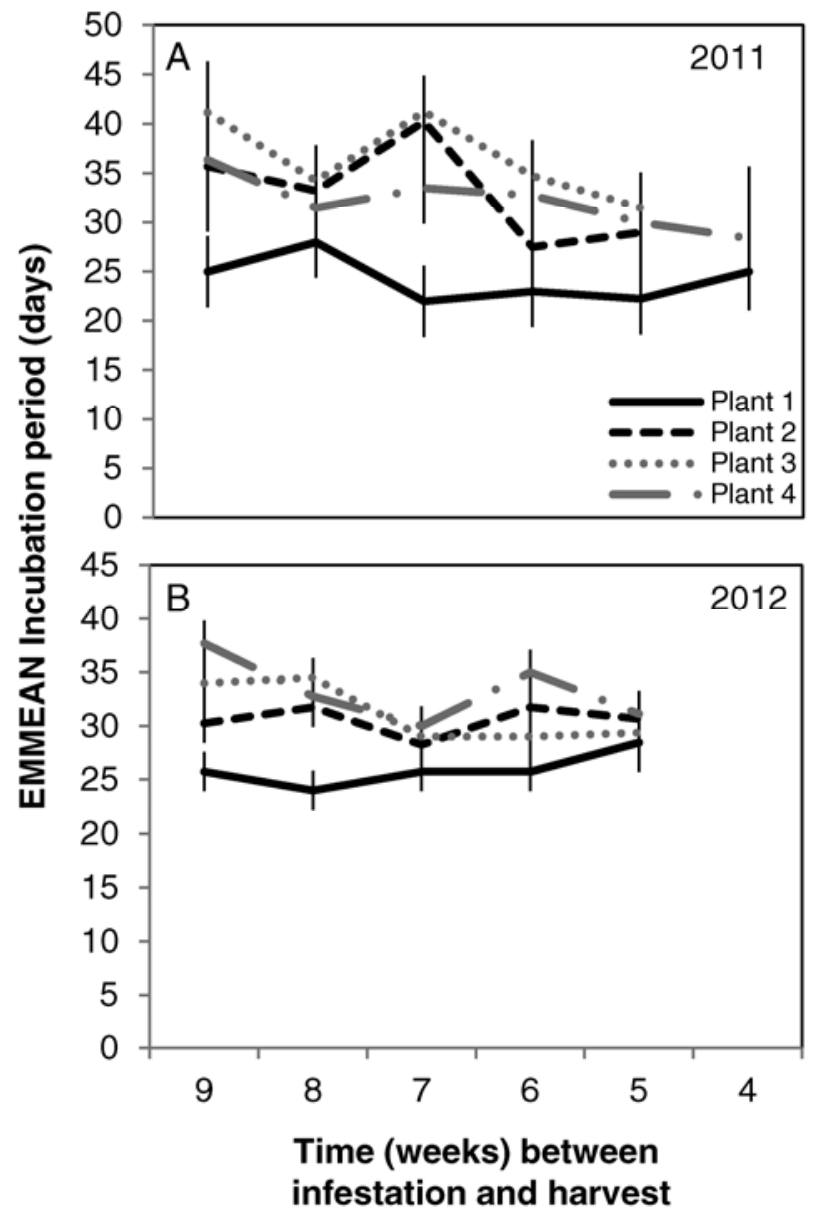

Fig. 3. Comparing estimated marginal means (EMMeans) for zebra chip disease incubation periods among four plants in experimental cages in A, 2011 and B, 2012. The $x$-axis represents different infestation treatments conducted on different weeks before harvest (durations of infection). Error bars represent standard errors $( \pm 1)$. ease incubation period; therefore, the results for each year are presented separately (Fig. 2A and B). Incubation period was not affected by plant replicate $\left(F_{3,28}=1.22, P=0.321\right)$ and this variable was not included in the final model. The onset of ZC symptoms occurred significantly earlier on plant 1 than on the other three plants in the cage (Fig. 3A and B), indicating lack of immediate vector dispersal following their release on plant 1 . Plants 2,3 , and 4 formed a homogenous statistical subset (Tukey's honestly significant difference [HSD], $P=0.168$; Fig. $3 \mathrm{~A}$ and $\mathrm{B}$ ) with regard to incubation period. Therefore, for consistency, analyses of the disease development in each cage only included the plant on which infective psyllids were released.

Similar to incubation period, the period before ' $\mathrm{Ca}$. L. solanacearum' was detected in leaf tissue was not affected by infestation treatment $\left(F_{6,49}=1.42, P=0.991\right)$. Plants infested 1 and 2 weeks before harvest were not included in this analysis because no pathogen was detected in their leaf tissue (however, see below). Year $\left(F_{1,38}=1.39, P=0.246\right)$, year-infestation $\left(F_{5,33}=1.47, P=\right.$ $0.239)$, and plant replicate $\left(F_{3,39}=2.00, P=0.130\right)$ were factors with no significant effect and were removed from the final model. Based on qPCR, the average number of days after infestation that ' $C a$. L. solanacearum' was detected in leaf tissue, for the first seven infestations, was between $25.4( \pm 1.6)$ (infestation 6$)$ and $27.4( \pm 3.91)$ (infestation 7). At the harvest, however, when the stem terminal was collected for pathogen analysis, detection time was reduced to 14 to 20 days after infestation. The pathogen was not detected in leaf or stem tissue of plants infested only a week before harvest.

The daily rate of $\mathrm{ZC}$ symptom development was consistent across the first five infestations $\left(F_{4,29}=1.69, P=0.178\right)$. There was no effect of year $\left(F_{1,24}=0.770, P=0.390\right)$, year-infestation $\left(F_{5,24}\right.$ $=1.36, P=0.273)$, or plant replicate $\left(F_{3,21}=0.680, P=0.564\right)$ on

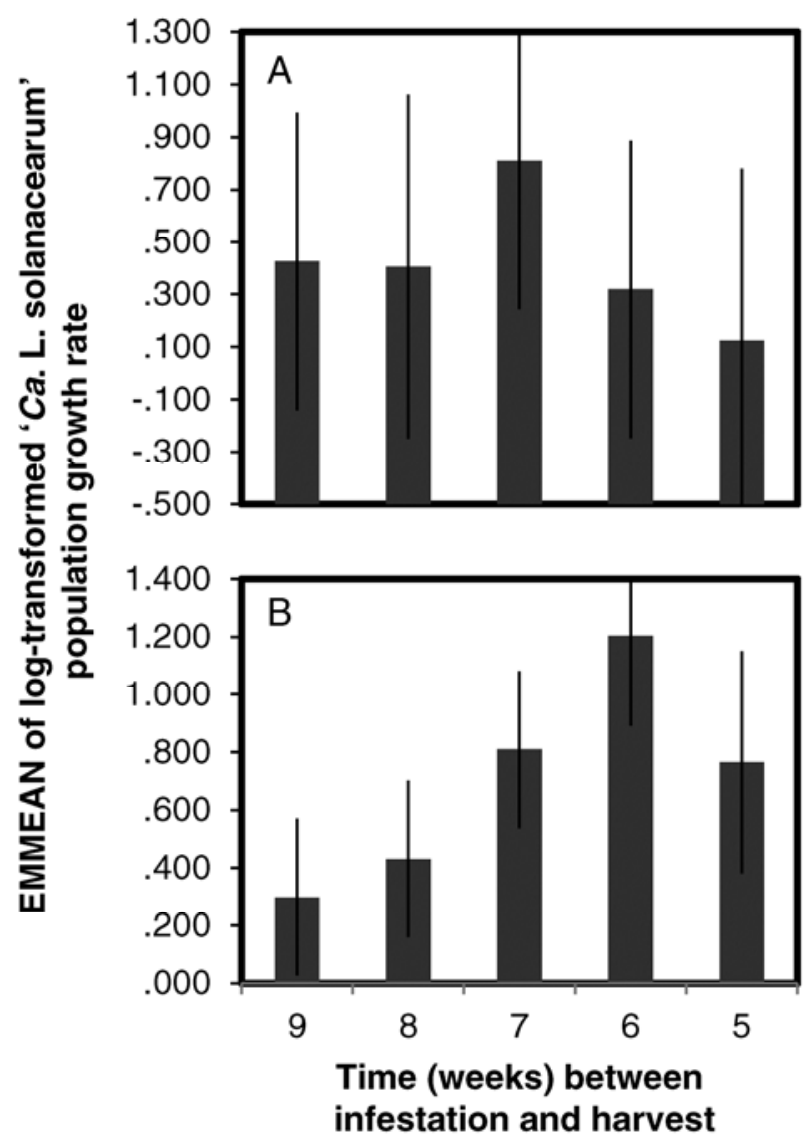

Fig. 4. Estimated marginal means of 'Candidatus Liberibacter solanacearum' population growth rate during the first five infestations (duration of infection $=5$ weeks or longer) in A, 2011 and B, 2012. Error bars represent 95\% confidence interval. 
the daily rate of symptom development. Nonsignificant factors were eliminated in a stepwise approach.

The daily rate of pathogen population growth was not statistically different among the first five infestation treatments, which coincided with relatively earlier stages of plant development $\left(F_{4,22}\right.$ $=2.76, P=0.053$; Fig. $4 \mathrm{~A}$ and $\mathrm{B})$. A significant effect of plant replicate was detected by the model $\left(F_{3,22}=5.57, P=0.005\right)$. There was also a significant effect of year $\left(F_{1,22}=6.68, P=0.017\right)$ and year-infestation interaction $\left(F_{4,22}=3.13, P=0.035\right)$; therefore, these are presented separately (Fig. 4A and B). In both years, there was a positive relationship between foliar ZC symptom severity and titer (Spearman $\rho=0.540, P<0.001$; Fig. 5A and B).

ZC development in potato tubers. There was a significant difference in the number of tubers exhibiting disease symptoms among plants infested at different times (infestation treatment) $\left(\chi^{2} 8\right.$ $=143.94, P<0.001)$. In plants which were infested 4 weeks before harvest or longer (the first five treatments), 80 to $95 \%$ of tubers exhibited ZC symptoms (Fig. 6). Only 32 and $1.3 \%$ of tubers were symptomatic in plants infested 3 and 2 weeks before harvest, respectively (Fig. 6). None of the tubers from plants infested 1 week before harvest exhibited any disease symptoms. The severity of symptoms in tubers at harvest varied significantly among infestation treatments $\left(F_{8,51}=62.71, P<0.001\right.$; Fig. $5 \mathrm{C}$ and D). Disease severity in tubers from plants that were infested 4 weeks or longer before harvest formed a homogenous statistical subset different from mean tuber symptom severity of plants infested 3 weeks before harvest (Fig. 5C and D). There was also a significant effect of year-infestation interaction $\left(F_{9,51}=4.68, P<0.001\right)$. Results of the 2011 and 2012 experiments are illustrated in separate figures (Fig. 5C and D). No significant effect of year was detected $\left(F_{1,48}=0.010, P=0.930\right)$. Variation in the severity of tuber symptoms was not influenced by the titer of the pathogen in tuber tissue when titer was treated as a covariate in the model $\left(F_{1,48}=0.286, P=0.595\right)$.

\section{A}

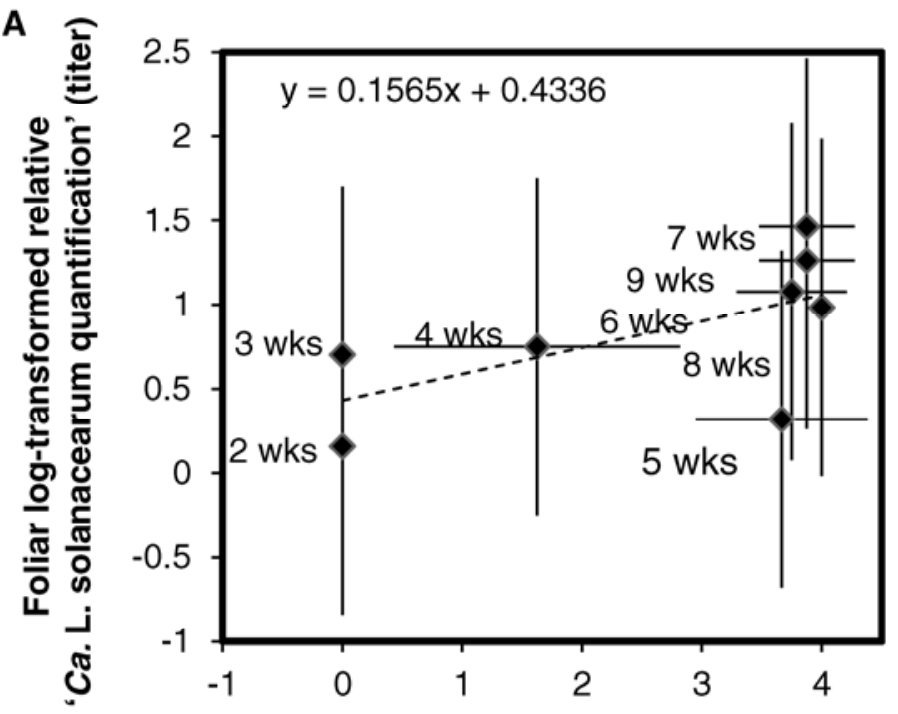

B



Mean foliar symptom severity score

C

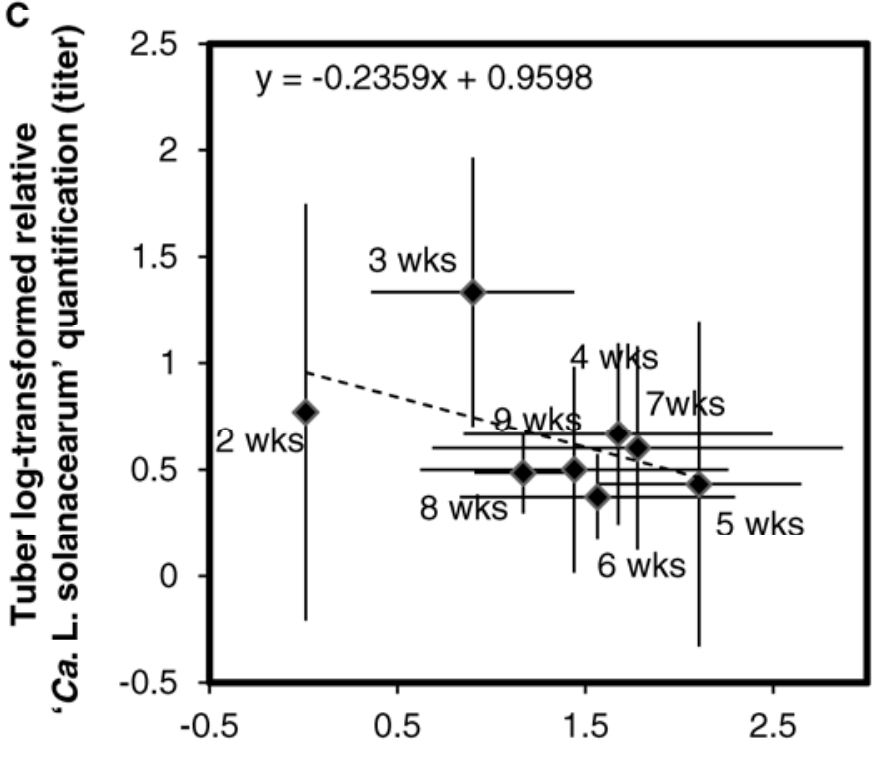

D

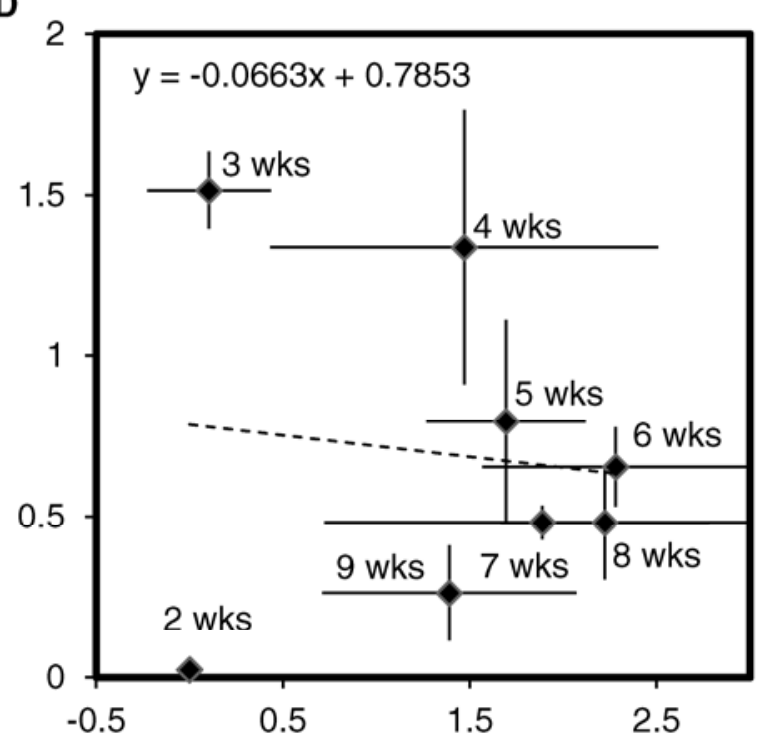

\section{Mean tuber symptom severity score}

Fig. 5. Relationship between bacterial titer and symptom severity in different infestation treatments in $\mathbf{A}$ and $\mathbf{B}$, aboveground and $\mathbf{C}$ and $\mathbf{D}$, belowground tissues. Numbers next to each point represent infection durations (weeks before harvest). A and C represent 2011 and B and D represent 2012 study results. Error bars represent $95 \%$ confidence interval. 
Similar to symptom severity, the titer of ' $\mathrm{Ca}$. L. solanacearum' varied among tubers from different infestations $\left(F_{8,63}=14.58, P<\right.$ $0.001)$. The pathogen was undetectable in plant tubers which were infested 1 week before harvest. In plants which were infested 2 weeks before harvest, ' $\mathrm{Ca}$. L. solanacearum' was detected in $74.3 \%$ of the tubers. However, only $1.3 \%$ of these tubers were symptomatic. Pathogen titers peaked in tubers from plants which were infested 3 weeks before harvest (Fig. 5C and D). In both years, a negative relationship was detected between ZC severity score and titer but it was not statistically significant (2011: Pearson correlation $[r]=-0.587, P=0.126 ; 2012: r=-0.414, P=0.308$; Fig. 5C and D).

ZC and potato yield. The number of tubers per plant was not affected by infestation treatment $\left(F_{9,67}=1.24, P=0.282\right)$. There was a significant effect of plant replicate on tuber production $\left(F_{3,67}\right.$ $=3.41, P=0.022)$; therefore, this variable was controlled for as a factor in the final model. No effect of year or year-infestation $(P>$ 0.30) was detected; these factors were excluded from the final model. Average tuber weight per plant, however, was significantly affected by the time of infestation and, thus, the growth stage in which the plant was infested $\left(F_{9,70}=12.84, P<0.001\right)$. Average tuber weight was significantly negatively correlated with the number of weeks before harvest in which infestations occurred $(\rho=$ $-0.712, P<0.001$; Fig. 7). Our post hoc Tukey's HSD indicated that plants which were infested within the last 3 weeks before harvest did not differ in their average tuber weight and formed a homogenous statistical subset along with the noninfested controls $(P$ $=0.352$ ). Plants infested 1,2 , and 3 weeks post emergence were placed together in a homogenous statistical subset $(P=0.569)$, forming a group that contained the smallest tubers (Fig. 7).

\section{Discussion}

The severity of tuber and foliar symptoms at harvest was determined by the time of infestation. The relationship between titer and symptom severity was different in aboveground and underground plant tissues. The pathogen titer increased in the foliage as symptom severity increased but, within tubers, there was a decreasing trend in ' $C a$. L. solanacearum' quantity as symptom severity increased. This difference may have been caused by localized and possibly different types of plant responses following ' $\mathrm{Ca}$. L. solanacearum' infection. For example, variations in the level of phenolics and peroxidase activity in infected potato tubers may follow a localized pattern, positively correlated with symptom severity and the duration of infection (20). Thus, the observed negative trend between titer and symptom severity, consistently in both years, may be due to reduction in pathogen population overtime as a result of cumulative physiological responses in tuber tissue.

Successful molecular detection of ' $\mathrm{Ca}$. L. solanacearum' in the leaf tissue coincided with the disease appearance, which was be-

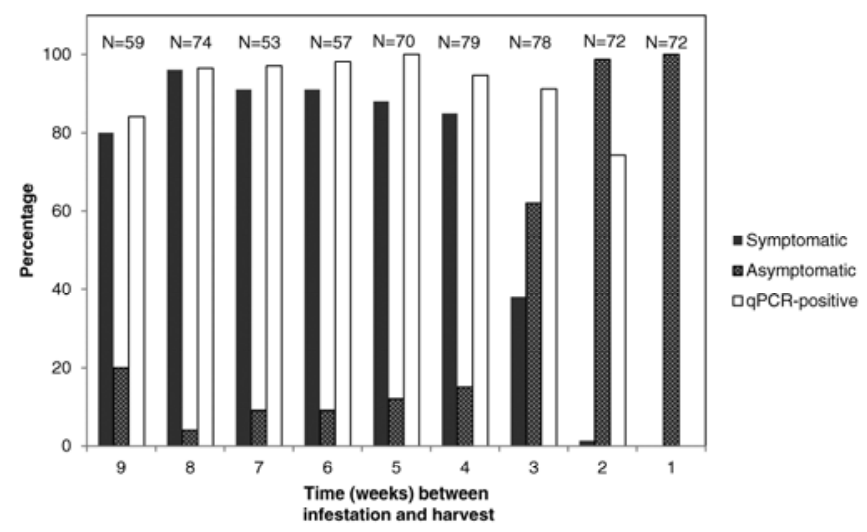

Fig. 6. Percentage of tubers with and without visual zebra chip disease symptoms and the percentage that tested positive for the pathogen. The $x$-axis = number of weeks following infestation, $\mathrm{N}=$ number of tubers evaluated per infestation treatment, and qPCR = quantitative polymerase chain reaction. tween 3 and 4 weeks after psyllid-infestation. However, in the terminal stem tissue the pathogen was detectable as early as 2 weeks post infestation, which was at least a week earlier than its detection in the leaf. This result supports a previous finding that ' $C a$. L. solanacearum' is heterogeneously distributed in planta, and that the pathogen is more readily detectable in the stem than leaf or petiole tissues (28). Despite high detection sensitivity in stem tissue, the pathogen remained undetectable in stem samples from plants exposed to infective psyllids $\leq 1$ week prior to harvest. In contrast to the first year of the study, in which all plants infested 4 weeks before harvest developed foliar disease symptoms, in the second year of the study (2012), plants infested 4 weeks before harvest did not develop foliar symptoms; an inconsistency which partially explained the observed year-infestation treatment interaction.

The incubation period for $\mathrm{ZC}$ was significantly shorter for the plant located at the point of release. The remaining three plants in each cage did not show symptoms until, on average, 7 to 9 days later (Fig. 3). However, because quantifying various aspects of ZC development in plants infected at different growth stages was the primary objective of this study, obtaining a uniform time of inoculation within each infestation treatment was essential. Therefore, only plants on which psyllids were initially released (plant 1) were included in the analyses. Although the exclusion of plants 2 to 4 reduced our sample size, the number of tubers obtained as well as the observed consistency in the disease appearance and progress in plant 1 across the infestations and between the 2 years provided adequate data to accomplish our objectives. The delayed disease appearance in plants 2 to 4 , compared with plant 1 , in each cage indicated a possible delay in psyllid dispersal inside cages following their release. This observation supports the speculation by Henne et al. (7) that the gradual weekly increase in disease incidence in the field $(7,29)$ may be due to potato psyllid movement behavior. In addition, Rashed et al. (19) showed that overall disease incubation period in plants infested with multiple psyllids was shorter than plants infested with a single infective psyllid. Therefore, among-plant differences in ZC incubation period within cages may also indicate that, during the 1 -week inoculation period, the majority of psyllids remained on the plant on which they were initially released. The fact that no difference was detected among the other three plants showed that psyllids had no preference for a particular plant position or direction. In cage studies, psyllid infestations should be conducted individually for each plant due to the

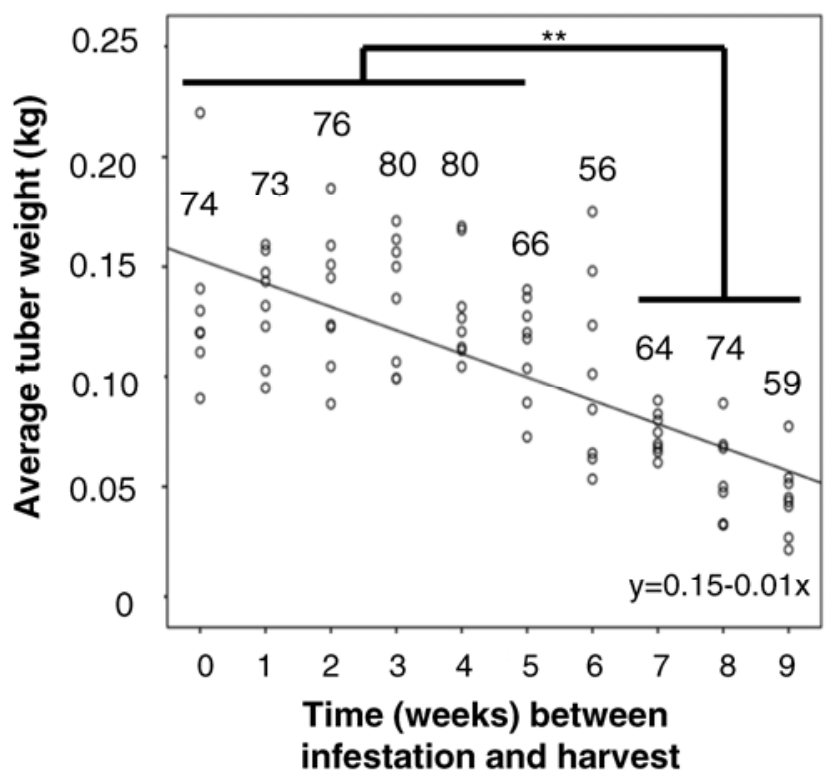

Fig. 7. Average tuber weight in relation to infection duration. Numbers represent total number of tubers in each of the infestation treatments. Asterisks indicate significant difference between the two compared groups $(P<0.001)$. 
limited tendency of psyllids to move after alighting on a suitable host.

Environmental factors are known to affect the pathogenicity of Liberibacter spp. and development of huanglongbing in citrus hosts $(1,15)$. Likewise, recent studies have indicated that $\mathrm{ZC}$ is influenced by ambient temperatures. Munyaneza et al. (18) reported that pathogen multiplication and symptom progress were reduced at temperatures between 12 and $17^{\circ} \mathrm{C}$ and stopped at temperatures above $32^{\circ} \mathrm{C}$. In their environmentally controlled study, the shortest disease incubation periods were at temperatures between 20 to 25 and 27 to $32^{\circ} \mathrm{C}$, an average of 20.7 and 30 days, respectively. In our study, for each infestation, the average daily temperature during the incubation period for each infestation treatment was within the optimal range for ZC incubation (18) (Fig 2). Our observed 3 to 4 weeks of $\mathrm{ZC}$ incubation supported previous reports under controlled optimal conditions (18). This was despite the fact that, in the field, experimental plants frequently experienced minimum temperatures lower than $17^{\circ} \mathrm{C}$ and maximum temperatures higher than $32^{\circ} \mathrm{C}$ (Fig 2). Therefore, natural environmental variations in the Texas Panhandle area had minimal impact on ZC incubation period. Constant exposures to extreme temperatures may be needed for disease development to be affected.

Following appearance of foliar ZC symptoms, the rate of symptom progress remained constant across all infestation treatments of different plant developmental stages. Likewise, the growth rate of the pathogen population was not affected by the developmental stage in which the plant was infested. However, significant year and year-infestation effects were detected. The significant interaction term revealed that infestation treatments behaved differently in 2011 and 2012 (Fig. 4). There are known to be large variations in ' $C a$. L. solanacearum' detection frequency and quantification among tissue samples collected from an infected potato plant, due to uneven within-plant spatiotemporal distribution of the pathogen $(10,28)$. Although newly developed leaves are reportedly suitable for pathogen detection (10), removing the first fully expanded leaf from a single stem on each plant and at each sampling event (potentially different from the previously sampled stem) may have contributed to the existing variation in this study.

Plants infested less than 6 weeks before harvest showed no significant reduction in tuber yield when compared with noninfested controls (Fig 6). Infestations conducted $\geq 7$ weeks before harvest, however, coincided with vegetative growth, tuber initiation, and early bulking stages (4), resulting in a significant reduction in yield. Buchman et al. (2) suggested that, in potato plants, the tuber formation process stops soon after infection in the relatively more susceptible 'Atlantic' potato. However, based on our results with the less susceptible FL 1867, even plants which were infested 7 to 11 days post emergence produced tubers. In a study by Buchman et al. (2), all plants were infested at the tuber initiation stage and a destructive sampling approach was used to evaluate tuber growth and symptom development. In contrast, in our study, plants were infested at different developmental stages, including early vegetative stage, and all of the formed tubers were harvested at the same time. This provided a higher-resolution assessment of disease appearance and progress as well as its effect on tuber yield in relation to potato plant developmental stages.

Although tuber weight was not affected when plants were infested several weeks before harvest, quality was reduced in tubers from plants infested as late as 2 weeks before harvest. For these plants, although the majority of tubers remained asymptomatic ( $98.7 \%$ ), more than $74 \%$ of these tubers tested positive for ' $\mathrm{Ca}$. L. solanacearum'. Shifts in tuber biochemistry in response to ' $\mathrm{Ca}$. L. solanacearum' can occur as early as 1 to 2 weeks post infection, soon after pathogen translocation into the tissue (20). This indicates that physiological alternations take place before symptom appearance affecting potato quality. Indeed, it has been reported that up to $40 \%$ of asymptomatic tubers from plants infested 2 weeks before harvest may express ZC symptoms after frying (21). Early symptoms of ZC in freshly cut potato tubers at harvest coincided with the earliest molecular detection of the pathogen in aboveground stem tissue. Therefore, development of initial disease symptoms within tubers can start as early as 2 weeks after plant infestation by infective-psyllids, a week earlier than previously reported (2). It is possible that the higher number of psyllids used in this study $(N=30)$ compared with Buchman et al. $(N=20)(2)$ contributed to earlier symptom appearance. Nonetheless, disease symptoms can appear in tuber tissue at least a week before they become visually detectable in foliage, a finding in agreement with Buchman et al. (2).

In this study, we showed that plant susceptibility to ' $\mathrm{Ca}$. L. solanacearum' was not affected by the developmental stage in which a potato host is infected. ZC incubation period, rate of progress in symptom severity, and the rate of titer increase remained consistent in plants which were infested at different times throughout the field season. However, potato yield was significantly reduced in potato plants infected at vegetative and early tuber initiation stages. Symptom severity was significantly affected by the time of infection during the growing season. Under natural circumstances, potato psyllid populations can move into potato fields during early stages of plant growth, leaving plenty of time for pathogen movement and multiplication within host tissue and for ZC development. Therefore, early control measures to contain psyllid populations are of particular importance. In addition, pathogen was detected in tubers from plants which were infested 2 weeks before harvest, even though a large majority of infected tubers were asymptomatic. Although ' $\mathrm{Ca}$. L. solanacearum' was not detectable in tubers from plants infested 1 week before harvest, recent suggestions of pathogen multiplication in postharvest tubers (22) highlights the importance of chemical management of potato psyllids until at least a week before harvest.

\section{Acknowledgments}

This research was funded by a United States Department of Agriculture Specialty Crop Research Initiative grant (number 2009-51181-20176). We thank our lab members for their help with different aspects of this field study.

\section{Literature Cited}

1. Bove, J. M. 2006. Huanglongbing: a destructive, newly emerging, centuryold disease of citrus. J. Plant. Pathol. 88:7-37.

2. Buchman, J. L., Fisher, T. W., Sengoda, V. G., and Munyaneza, J. E. 2012. Zebra chip progression: from inoculation of potato plants with Liberibacter to development of disease symptoms in tubers. Am. J. Pot. Res. 89:159-168.

3. Buchman, J. L., Sengoda, V. G., and Munyaneza, J. E. 2011. Vector transmission efficiency of Liberibacter by Bactericera cockerelli (Hemiptera: Triozidae) in zebra chip potato disease: effects of psyllid life stage and inoculation access period. J. Econ. Entomol. 104:1486-1495.

4. Dwelle, R. B. 2003. Potato growth and development. Pages 9-11 in: Potato Production Systems. J. G. Stark and S. L. Love, eds. University of Idaho Agricultural Communications.

5. Goolsby, J. A, Adamczyk, J. J., Crosslin, J. M., Troxclair, N. N., Anciso, J. R., Bester, G. G. Bradshaw, J. D., Bynum, E. D., Carpio, L. A., Henne, D. C., Joshi, A., Munyaneza, J. E., Porter, P., Sloderbeck, P. E., and Supak, J. R. 2012. Seasonal population dynamics of the potato psyllid (Hemiptera: Triozidae) and its associated pathogen 'Candidatus Liberibacter solanacearum' in potatoes in the southern Great Plains of North America. J. Econ. Entomol. 105:1268-1276.

6. Hansen, A. K., Trumble, J. T., Stouthamer, R., and Paine, T. D. 2008. A new huanglongbing species, 'Candidatus Liberibacter psyllaurous,' found to infect tomato and potato, is vectored by psyllid Bactericera cockerelli (Sulc). Appl. Environ. Microbiol. 74:5862-5865.

7. Henne, D. C., Workneh, F., and Rush C. M. 2012. Spatial patterns and spread of potato zebra chip disease in the Texas Panhandle. Plant Dis. 96:948-956.

8. Irwin, M. E., and Thresh, J. M. 1990. Epidemiology of Barley yellow dwarf: A study in ecological complexity. Annu. Rev. Phytopathol. 28:393-424.

9. Jagoueix, S., Bove J. M., and Garnier, M. 1994. PCR detection of the two 'Candidatus Liberibacter' species associated with greening disease of citrus. Mol. Cell. Probe 10:43-50.

10. Levy, J., A. Ravindran, Gross, D., Tamborindeguy, C., and Pierson, E. 2011. Translocation of 'Candidatus Liberibacter solanacearum', the zebra chip pathogen, in potato and tomato. Phytopathology 101:1285-1291.

11. Li, W., Abad, J. A., French-Monar, R. D., Rascoe, J., Wen, A., Gudmestad, N. C., Secor, G. A., Lee, I., Duan, Y., and Levy, L. 2009. Multiplex realtime PCR for detection, identification and quantification of 'Candidatus Liberibacter solanacearum' in potato plants with zebra chip. J. Microbiol. Methods 78:59-65.

12. Li, W., Hartung, J. S., and Levy, L. 2006. Quantitative real-time PCR for 
detection and identification of "Candidatus Liberibacter" species associated with citrus huanglongbing. J. Microbiol. Methods 66:104-115.

13. Liefting, L. W., Perez-Egusquiza, Z. C., Clover, G. R. G., and Anderson, J. A. D. 2009. A new 'Candidatus Liberibacter' species in Solanum tuberosum in New Zealand. Plant Dis. 92:1474.

14. Lin, H., Lou, B., Glynn, J. M., Doddapaneni, H., Civerolo, E. L., Chen, C., Duan, Y., Zhou, L., and Vahling, C. M. 2011. The complete genome sequence of 'Candidatus Liberibacter solanacearum', the bacterium associated with potato zebra chip disease. PLoS One 6:e19135.

15. Lopes, S. A. Frare, G. F. Bertolini E., Cambra M., Fernandes, N. G., Ayres A.J. Martin D. R., and Bove, J. M. 2009. Liberibacter associated with citrus haunglongbing in Brazil: 'Candidatus Liberibacter asiaticus' is heat tolerant, ' $C a$. L. americanus' is heat sensitive. Plant Dis. 93:257-262.

16. Munyaneza, J. E., Crosslin, J. M., and Buchman, J. L. 2009. Seasonal occurrence and abundance of the potato psyllid, Bactericera cockerelli, in south central Washington. Am. J. Pot. Res. 86:513-518.

17. Munyaneza, J. E., Crosslin, J. M., and Upton, J. E. 2007. Association of Bactericera cockerelli (Homoptera: Psyllidae) with "Zebra Chip," a new potato disease in southwestern United States and Mexico. J. Econ. Entomol. 100:656-663

18. Munyaneza, J. E., Sangoda, V. G., Buchman, J. L., and Fisher, T. W. 2012. Effects of temperature on 'Candidatus Liberibacter solanacearum' and zebra chip potato disease symptom development. Plant Dis. 96:18-23.

19. Rashed, A., Nash, D., Paetzold, L., Workneh, F., and Rush, C. M. 2012. Transmission efficiency of 'Candidatus Liberibacter solanacearum' and potato zebra chip disease progress in relation to pathogen titer, vector numbers and feeding sites. Phytopathology 102:1072-1085.

20. Rashed, A., Wallis, C. M., Paetzold, L., Workneh, F., and Rush, C. M. 2013. Zebra chip disease and potato biochemistry: tuber physiological changes in response to 'Candidatus Liberibacter solanacearum' infection over time. Phytopathology 103:419-426.

21. Rashed, A., Workneh, F., Gray, J., Paetzold, L., and Rush, C. M. 2011. Relationship between time of infestation, disease development and tuber yield. Pages 22-26 in: Proc. 11th Annu. SCRI Zebra Chip Rep. Session. F. Workneh, A. Rashed, and C. M. Rush, eds. Fredric Printing, Aurora, CO.

22. Rush, C. M., Workneh, F., Rashed, A., Paetzold, L. 2012. Impact of late season psyllid infestations on potato seed quality. Pages 17-21 in: Proc. 11th Annu. SCRI Zebra Chip Rep. Session. F. Workneh, A. Rashed, and C. M. Rush, eds. Fredric Printing, Aurora, CO

23. Secor, G. A., Rivera, V. V., Abad, J. A., Lee, I. M., Clover, G. R. G., Liefting, L. W., Li, X., and De Boer, S. H. 2009. Association of 'Candidatus Liberibacter solanacearum' with zebra chip disease of potato established by graft and psyllid transmission, electron microscopy, and PCR. Plant Dis. 93:574-583

24. Stadler, R. H., Blank, I., Varga, N., Robert, F., Hau, J., Guy, P. A., Robert, M. C., and Riediker, S. 2002. Acrylamide from Maillard reaction products. Nature 419:449-450.

25. Swisher, K. D., Munyaneza, J. E., Crosslin, J. M. 2012. High resolution melting analysis of the cytochrome oxidase I gene identifies three haplotypes of the potato psyllid in the United States. Environ. Entomol. 41:10191028 .

26. Wallis, C. M., Chen, J., and Civerolo, E. L. 2012. Zebra chip-diseased potato tubers are characterized by increased levels of host phenolics, amino acids, and defense-related proteins. Physiol. Mol. Plant Pathol. 78:66-72.

27. Wen, A., Johnson, C., and Gudmestad, N.C. 2012. Comparison and evaluation of 'Candidatus Liberibacter solanacearum' haplotyping markers. Pages 104-107 in: Proc. 12th Annu. SCRI Zebra Chip Rep. Session. F. Workneh, A. Rashed, and C. M. Rush, eds. Fredric Printing, Aurora, CO.

28. Wen, A., Mallik, I., Alvarado, V. Y., Pasche, J. S., Wang, X., Li, W., Levy, L., Lin, H., Scholthof, H.B., Mirkov, T. E., Rush, C. M., and Gudmestad, N. C. 2009. Detection, distribution, and genetic variability of 'Candidatus $\mathrm{Li}$ beribacter' species associated with zebra chip complex disease 1 of potato in North America. Plant Dis. 93:1102-1115.

29. Workneh, F., Henne, D. C., Childers, A.C., Paetzold, L., and Rush, C. M. 2012. Assessment of the edge effect in intensity of potato zebra chip disease. Plant Dis. 96:943-947. 